\title{
Praktik mistisisme Jawa dalam novel Mantra Pejinak Ular karya Kuntowijoyo
}

\author{
Arif Setiawana, $1^{*}$ \\ aniversitas Muhammadiyah Malang, Jalan Raya Tlogomas 246, Malang, 6514, Indonesia \\ ${ }^{1}$ arifsetiawan@umm.ac.id
}

* Corresponding Author

\begin{tabular}{l}
\hline INFO ARTIKEL \\
\hline Sejarah Artikel: \\
Diterima: 25 September 2021 \\
Direvisi: 26 Oktober 2021 \\
Disetujui: 31 Oktober 2021 \\
Tersedia Daring: 31 Oktober \\
2021 \\
\hline
\end{tabular}

Kata Kunci:

Hakekat

Mistisisme Jawa

Praktik

Syariat

\author{
ABSTRAK
}

Mistisisme dalam tataran masyarakat Jawa menjadi salah satu hal yang tidak dapat dipisahkan dalam setiap perilaku yang terjadi di tengah masyarakat. Penelitian ini bertujuan untuk mendeskripsikan praktik mistisisme Jawa dalam novel Mantra Pejinak Ular karya Kuntowijoyo. Penelitian ini menggunakan metode deskriptif kualitatif, pendekatan yang digunakan adalah sosiologi sastra. Sumber data dalam penelitian ini adalah novel Mantra Pejinak Ular karya Kuntowijoyo yang diterbitkan oleh Penerbit Buku Kompas. Data dalam penelitian ini mencakup satuan cerita yang terwujud dalam dialog, monolog, paragraf, sekuen cerita, bagian kalimat, maupun narasi tokoh yang menggambarkan praktik mistisisme Jawa dalam novel Mantra Pejinak Ular karya Kuntowijoyo. Pengumpulan data dilakukan dengan langkah (a) membaca sumber data; (b) unitizing (mengambil data yang tepat dengan cara menandai teks; serta (c) mencatat dan menginventarisasi teks yang relevan. Analisis data dilakukan dengan menggunakan flow model of analysis yang dikemukakan oleh Miles dan Huberman. Hasil penelitian menunjukkan bahwa dalam novel Mantra Pejinak Ular karya Kuntowijoyo menunjukkan praktik mistisisme Jawa pada tingkatan sarengat/syariat dan tingkatan hakekat. Praktik mistisisme Jawa pada tingkatan sarengat/syariat dibuktikan dengan (1) percaya pada benda mitologi dan (2) percaya pada mitos-mitos. Pada tingkatan hakekat dibuktikan dengan ibadah yang dilakukan untuk menemui Tuhan dalam bentuk salat istikharah. Berdasarkan hasil penelitian, maka dapat disimpulkan bahwa praktik mistisisme Jawa yang dominan dilakukan oleh masyarakat Jawa dalam novel Mantra Pejinak Ular karya Kuntowijoyo adalah pada tingkatan sarengat/syariat dan hakekat.

\section{ABSTRACT}

Keywords:

Hakekat Mysticism at the level of Javanese society is one thing that cannot be

Javanese Misticism

Practice

Syariat separated in every behavior that occurs in society. This study aims to describe the practice of Javanese mysticism in the novel Mantra Pejinak Ular by Kuntowijoyo. This study uses a qualitative descriptive method, the approach used is the sociology of literature. The data source in this study is the novel Mantra Pejinak Snake by Kuntowijoyo published by Kompas Book Publishers. The data in this study include story units that are manifested in dialogues, monologues, paragraphs, story sequences, sentence sections, and character narratives that describe the practice of Javanese mysticism in the novel Mantra Pejinak Ular by Kuntowijoyo. Data collection is done by steps (a) reading the data source; (b) unitizing (taking the right data by marking the text; and (c) recording and inventorying relevant texts. Data analysis was carried out using the flow model of analysis proposed by Miles and Huberman. The results showed that in the novel Mantra Pejinak Ular Kuntowijoyo's work shows the practice of Javanese mysticism at the sarengat/syariat level and the essence level. The practice of Javanese mysticism at the sarengat/syariat level is proven by (1) believing in mythological objects and (2) believing in myths. Based on the results of the research, it can be concluded that the 
dominant practice of Javanese mysticism carried out by the Javanese people in the novel Mantra Pejinak Ular by Kuntowijoyo is at the level of sarengat/syariat and essence.

(C) 2021, Arif Setiawan

This is an open access article under CC-BY license

\section{Pendahuluan}

Karya sastra merupakan media yang sering digunakan oleh pengarang dalam mengekspresikan dan melukiskan miniatur kehidupan (Budiman, 2016). Berdasarkan kondisi tersebut, pengarang telah mengajak pembaca untuk memahami dan menyelami fenomena sosial yang terhampar di masyarakat (Yudari, 2019). Fenomena sosial yang tergambar dalam novel merupakan manifestasi budaya satu masyarakat (Djono, Utomo, \& Subiyantoro, 2012). Manifestasi budaya yang sering diangkat dalam karya sastra selalu menyesuaikan dengan latar belakang pengarang. Hal ini juga tampak dalam salah satu karya sastra yang ditulis oleh Kuntowijoyo pada tahun 2013, dan menjadi representasi budaya Jawa sesuai dengan latar belakang pengarang.

Kuntowijoyo dikenal sebagai budayawan, sejarawan, dan sastrawan yang sangat produktif di masanya (Kasanova \& Widjajanti, 2018). Telah banyak karya yang dihasilkan dengan mengusung nafas budaya, sejarah, sastra, dan juga agama (Kasanova \& Widjajanti, 2018). Salah satu karya sastra yang dihasilkan oleh Kuntowijoyo dengan memadukan antara budaya Jawa dengan Islam adalah novel Mantra Pejinak Ular. Novel Mantra Pejinak Ular menyuguhkan gambaran realitas kehidupan masyarakat Jawa Tengah yang teramat kompleks. Dimulai dari kehidupan di sebuah desa yang berada jauh dari pusat keramaian, pembaca diajak untuk mengikuti dan menyelami kisah bahagia, sedih, kejahatan, kecurangan, ketidakadilan hingga politik yang berbau KKN. Balutan cerita diperankan oleh seorang Abu Kasan Sapari yang merupakan keturunan priyayi Jawa yang dibesarkan dengan konsep pendidikan Islam dan budaya Jawa di akhir era kepemimpinan Orde Baru. Dengan pendidikan Islam dan balutan budaya Jawa, Abu Kasan Sapari dapat memaknai beberapa simbol alam yang terjadi di akhir era kepemimpinan Orde Baru. Hal inilah yang menjadikan novel ini menarik untuk dijadikan sebagai objek kajian dalam penelitian ini. Selain itu, penghargaan yang diterima dari Majelis Sastra Asia Tenggara (Mastera), juga semakin menguatkan bahwa novel ini layak digunakan sebagai salah satu objek kajian dalam penelitian ini.

Novel Mantra Pejinak Ular merupakan salah satu karya sastra yang berpijak pada kebudayaan Jawa-Islam (Wahidi, 2013). Nilai budaya yang sangat dominan tergambar dalam novel ini lebih banyak bercerita tentang fenomena sosial yang dibalut dengan budaya Jawa (Widijanto, 2018; Windayanto, 2020), serta dibumbui dengan hal-hal yang berbau mitos seputar sosial, politik, dan budaya (Ichsan \& Hanafiah, 2020; Wardhani, Arditama, Noe, \& Narimo, 2021; Yudari, 2019). Selain itu, dalam novel ini juga menyuguhkan balutan konsep pewayangan yang diceritakan secara lugas (Thalib, 2014), serta menekankan pada simbol-simbol masyarakat Jawa yang mudah untuk dipahami (Wardhani et al., 2021).

\section{Novel Mantra Pejinak}

Ular menggambarkan kehidupan sosok Abu Kasan Sapari, seorang pegawai kecamatan di kaki gunung Lawu yang juga merupakan seorang dalang wayang yang handal dan kreatif dalam menghadapi sebuah kemelut 
politik tingkat desa. Abu Kasan Sapari yang belum memiliki pengalaman ataupun hasrat untuk berpolitik justru menemukan dirinya di tengah-tengah badai pertarungan politik di daerahnya karena kemampuannya mendalang. Walaupun pertarungan politik itu tidak diceritakan secara gamblang dan terekspos secara terbuka, namun dengan beragam perlambang yang digunakan Kuntowijoyo, tetap terasa intrik-intrik yang dilancarkan pihak tertentu untuk memuluskan jalannya mencapai kemenangan politis. Selain unsur politis yang diangkat oleh Kuntowijoyo, masih ada unsur budaya yang sangat erat digambarkan dalam novel ini. Kuntowijoyo menggambarkan khazanah budaya Jawa dalam novel ini melalui wayang serta kehidupan masyarakat Jawa yang tidak bisa lepas dari mitos yang secara turun temurun telah diwariskan oleh nenek moyang. Melalui rentetan cerita dan tingkah laku tokoh yang dihadirkan dalam novel Mantra Pejinak Ular tersebut, Kuntowijoyo menggambarkan berbagai macam lakuan tokoh yang menunjukkan perilaku masyarakat dengan representasi budaya Jawa. Hal inilah yang menjadikan novel Mantra Pejinak Ular menraik untuk dijadikan sebagai objek penelitian.

Simbol dalam budaya Jawa merupakan suatu kaitan yang tak terpisahkan dengan agama dan budaya asli Jawa secara keseluruhan (Chalik, 2015). Simbol oleh orang Jawa dijadikan sebagai pegangan bagi sebagian besar penganut mistisisme (Budiman, 2016; Miswari, 2017). Hal ini dikarenakan mistisisme Jawa yang dianut oleh sebagian besar masyarakat mendasarkan aspek kehidupannya pada simbol-simbol (Bukhori, 2012; Rudin, 2017). Selain itu, simbol dalam konteks mistisisme Jawa digunakan sebagai salah satu bentuk perjalanan batin untuk mendapatkan kesempurnaan diri dalam penyatuannya dengan Tuhan (Aksan, 2018; Mashadi, 2013; Thalib, 2014). Secara umum mistisisme Jawa dapat dikatakan sebagai upaya penebusan serta pengetahuan mengenai alam raya dengan tujuan mengadakan hubungan langsung dengan Tuhan, sesama manusia, dan lingkungan (Rudin, 2017; Setiawan \& Musaffak, 2019; Wahidi, 2013). Berdasarkan konsep tersebut, dapat disimpulkan bahwa mistisisme Jawa tidak didasarkan pada doktrin tertentu (Thohir, 2012), melainkan merupakan akumulasi proses berdasarkan pengalaman hidup masing-masing individu (Wardhani et al., 2021). Pengalaman hidup yang membawa keyakinan dan religiositas yang bersifat individu (Ichsan \& Hanafiah, 2020), sehingga pada tataran ini semua urusannya bersifat sangat rahasia dan tertutup (Budiman, 2016; Thalib, 2014). Bentuk keyakinan dan religiositas yang bersandar pada tataran pribadi, tentu memiliki kadar yang berbeda-beda pada setiap individunya (Miswari, 2017; Nawafi, 2020; Thalib, 2014).

Dalam praktiknya, mistisisme Jawa adalah upaya yang dilakukan oleh individu guna mencapai tingkat tertinggi terhadap kepercayaan yang dianutnya (Furqon \& Busro, 2017). Upaya yang dilakukan tersebut dilakukan sebagai wujud pencarian tunggal manusia yang menghendaki penyatuan kembali dengan asalnya (Penciptanya) (Furqon \& Busro, 2017; Rudin, 2017). Hal ini dilakukan sebagai bentuk pelepasan terhadap segala ikatan duniawi yang selama ini terasa begitu dekat (Nawafi, 2020; Yudari, 2019). Perjalanan mistis yang dilakukan manusia dilakukan melalui empat tahapan yang cukup kompleks yaitu, syariat, hakekat, tarekat, dan makrifat (Mulder, 2013). Adapun masing-masing tingkatan praktik mistisisme Jawa menurut Mulder dapat dijabarkan sebagaimana berikut, sarengat/syariat merupakan tingkatan yang paling dasar dalam praktik mistisisme Jawa, pada tingkatan ini semua hal lebih diarahkan dalam bentuk percaya terhadap keberadaan ajaran agama, dewa, dukun, roh, jin, setan, mitos-mitos serta benda-benda mitologi berupa keris, panah, pedang, tombak, dll (Mulder, 2013). Hakekat merupakan tingkatan dimana ibadah yang telah dilakukan bukan hanya sekedar 
menggerakan anggota tubuh dan melafalkan bacaan, melainkan upaya yang dilakukan untuk menjumpai Tuhan dalam keberadaan diri yang paling dalam (Mulder, 2013). Tarekat, merupakan tingkatan yang mengarah pada bagaimana individu mencari jalan atau petunjuk untuk melakukan ibadah yang sesuai dengan ajaran yang ditentukan, sehingga dapat menjadi salah satu jalan untuk menemui Tuhan (Mulder, 2013). Tingkatan makripat, merupakan tahapan yang paling tinggi karena tujuan setiap individu telah menyatu dengan Tuhan (Mulder, 2013). Penelitian ini bertujuan untuk mengaji praktik mistisisme Jawa berdasarkan tingkatannya dalam novel Mantra Pejinak Ular karya Kuntowijoyo.

Sebagai referensi yang berguna untuk pembanding, penelitian ini menggunakan beberapa hasil penelitian terdahulu untuk menarik perbandingan. Pertama, penelitian (Parini, 2014) yang mengangkat judul "Aspek Religiusitas Novel Mantra Pejinak Ular Karya Kuntowijoyo: Kajian Semiotik dan Implementasinya sebagai Bahan Ajar Sastra di SMP". Hasil penelitian (1) permasalahan kehidupan masyarakat yang dideskripsikan melalui nilai budaya, nilai politik, dan nilai percintaan, dan (2) penyampaian permasalahan dilakukan melalui berbagai peristiwa yang dialami oleh tokoh. Kedua, penelitian (Kasanova \& Widjajanti, 2018) berjudul "Mitos dan kontramitos dalam novel Mantra Pejinak Ular karya Kuntowijoyo". Hasil penelitian menunjukkan bahwa (1) dalam novel Mantra Pejinak Ular kental dengan mitos yang bersifat kosmologi, yaitu mitos yang berhubungan dengan alam, dan (2) kontramitos dalam novel Mantra Pejinak Ular mengajak masyarakat untuk meninggalkan mantra-mantra yang berbasis mitos, mistik, dan klenik. Ketiga, penelitian yang dilakukan oleh (Sumiyardana, 2018) yang mengusung judul "Kesesuaian Masyarakat Jawa dalam Novel Mantra Pejinak Ular dengan Realita: Analisis Sosiologi Sastra". Hasil penelitian menunjukkan bahwa penggambaran masyarakat Jawa dalam novel Mantra
Pejinak Ular telah digambarkan berdasarkan kondisi nyata masyarakat Jawa. Hal ini membuktikan bahwa novel Mantra Pejinak Ular dihasilkan berdasarkan observasi dan penghayatan pengarang terhadap realitas kehidupan masyarkat Jawa. Keempat, penelitian dengan judul "Cermin kehidupan masyarakat pedesaan dalam novel Mantra Pejinak Ular karya Kuntowijoyo: Sebuah kajian sosiologi sastra" yang dilakukan oleh (Mardiani, 2017). Adapun hasil penelitian ini menunjukkan bahwa permasalahan kehidupan dalam novel Mantra Pejinak Ular dideskripsikan melalui nilai budaya, nilai politik, dan nilai percintaan. Kelima, penelitian yang dilakukan oleh (Setiawan \& Musaffak, 2020) dengan judul "Praktik Mistisisme Jawa dalam novel Partikel karya Dewi Lestari”. Penelitian ini juga mengaji mengenai praktik mistisisme Jawa dalam novel Partikel karya Dewi Lestari. Hasil penelitian ini menunjukkan bahwa tingkatan praktik mistisisme Jawa dalam novel Partikel pada tingkatan syariat, yang dibuktikan dengan percaya kepada jin dan mitos. Perbedaan dengan penelitian (Setiawan \& Musaffak, 2020) antara lain, (1) objek kajian yang digunakan, (2) tujuan penelitian yang hanya memfokuskan pada satu tingkatan praktik mistisisme Jawa dalam novel Partikel yaitu syariat, sedangkan dalam penelitian ini tingkatan praktik mistisisme Jawa yang dilakukan sampai pada tingkatan hakekat. Kajian terhadap praktik mistisisme Jawa dalam novel Mantra Pejinak Ular karya Kuntowijoyo diharapkan dapat memberikan kontribusi untuk memperluas pandangan atas pengkajianpengkajian mengenai novel Mantra Pejinak Ular dan penelitian yang mengungkap unsur budaya Jawa yang sebelumnya sudah ada. Selain itu, penelitian ini juga berkontribusi untuk mengingatkan kembali mengenai kearifan lokal khususnya Jawa.

\section{Metode}

Berdasarkan tujuan penelitian yang telah dipaparkan, metode yang digunakan adalah metode deskriptif kualitatif. Metode ini digunakan untuk mendeskripsikan dan 
menginterpretasikan data-data yang tertulis dalam novel Mantra Pejinak Ular karya Kuntowijoyo. Jenis penelitian ini adalah kualitatif, sedangkan pendekatan yang digunakan dalam penelitian ini adalah sosiologi sastra. Secara khusus, pendekatan sosiologi sastra yang digunakan adalah sosiologi karya sastra. Hal ini karena teks novel Mantra Pejinak Ular karya Kuntowijoyo merupakan fokus analisis satusatunya. Penelitian ini tidak menggunakan unsur sosiologis lain, baik yang berasal dari dimensi sosiologi pengarang maupun sosiologi pembaca sebagai unit analisis.

Sumber data penelitian ini adalah novel Mantra Pejinak Ular karya Kuntowijoyo yang diterbitkan oleh Penerbit Buku Kompas dengan jumlah 274 halaman pada tahun 2013. Data dalam penelitian ini mencakup satuan cerita yang terwujud dalam dialog, monolog, paragraf, sekuen cerita, bagian kalimat, maupun narasi tokoh yang menggambarkan praktik mistisisme Jawa dalam novel Mantra Pejinak Ular karya Kuntowijoyo.

Pengumpulan data dilakukan dengan langkah berdasarkan pedoman pengumpulan data yang telah dikemukakan oleh Creswell (2014) yang terdiri dari yaitu (a) pembacaan terhadap sumber data; (b) pengambilan data dengan cara memberikan penanda pada teks; dan (c) pencatatan dan penginventarisan teks yang relevan. Model analisis data yang digunakan adalah flow model of analysis yang dikemukakan oleh (Miles \& Huberman, 1994). Di mana proses kerjanya dilakukan dengan langkah-langkah seleksi data, (2) paparan data, dan (3) penarikan kesimpulan. Pada tahapan seleksi data dilakukan proses reduksi terhadap datadata yang telah dikumpulkan. Reduksi diarahkan pada data yang memiliki kesamaan ataupun datadi luar fokus analisis. Tahapan paparan data dilakukan dengan menyajikan data dalam bentuk kutipan teks. Data yang telah dipaparkan kemudian dianalisis menggunakan teori yang digunakan dalam penelitian ini. Hasil interpretasi disandingkan dengan temuan penelitian lain. Terakhir, dilakukan penarikan simpulan atas hasil penelitian yang telah didapatkan.

\section{Hasil dan Pembahasan}

Pada bagian hasil dan pembahasan diuraikan analisis data terkait dengan praktik mistisisme Jawa yang digambarkan dalam novel Mantra Pejinak Ular karya Kuntowijoyo. Kutipan data dalam novel yang terkait dengan praktik mistisisme Jawa selanjutnya akan diinterpetasikan kembali menurut kajian teori mistisisme Jawa untuk melihat detail substansi tentang praktik mistisisme Jawa. Pada bagian ini dipaparkan tiga pembahasan, yaitu praktik mistisisme Jawa pada tingkatan syareat dalam bentuk percaya pada benda mitologi, praktik mistisisme Jawa pada tingkatan syareat dalam bentuk percaya pada mitos-mitos, dan praktik mistisisme Jawa pada tingkatan hakekat dalam bentuk ibadah sebagai upaya untuk menemui Tuhan.

\subsection{Praktik Mistisisme Jawa pada Tingkatan Syareat dalam Bentuk Percaya pada Benda Mitologi}

Praktik mistisisme yang dilakukan oleh masyarakat Jawa telah terjadi secara turun temurun dari satu generasi ke generasi selanjutnya. Sebagai sebuah produk budaya, praktik mistisisme dipercaya sebagai kebenaran oleh masyarakat Jawa. Karenanya, selain melembaga dalam sistem budaya masyarakat, praktik mistisisme ditransmisikan dari satu generasi ke generasi lain tanpa adanya penolakan dari generasi muda. Siklus ini terus berulang dan menjadi praktik kepercayaan yang diterima dan diyakini kebenarannya oleh masyarakat.

Salah satu bentuk praktik mistisisme di tengah masyarakat Jawa adalah percaya terhadap benda-benda mitologi seperti keris, panah, dan tombak. Kepercayaan ini telah mengakar kuat dalam sistem kepercayana masyarakat Jawa. Kepercayaan terhadap benda mitologi ini diyakini akan membawa banyak manfaat pada individu yang percaya dan menjalaninya dengan baik. Hal ini juga terbukti dalam kutipan data berikut. 
"Kepyak yang bisa bunyi crek-crek-crek dalam wayang dan gamelan itu biasanya terbuat dari perunggu, yaitu campuran dari tembaga dan timah. Dalam wayang ada 15 macam bunyi-bunyian, biasanya hanya dimainkan oleh 10 orang, jadi harus ada yang dapat memainkan dua instrumen. Gamelan merupakan bukti bahwa nenek-moyang kita itu sudah hidup menetap, bercocok tanam dan beternak. Artinya, tidak lagi berburu dan berpindah-pindah tempat. Bagaimana tidak, untuk menggotong gamelan kesana-kemari itu sulit. Gamelan itu dapat membuat orang trance. Kalau gamelan hanya dipukul ning-nong terus menerus pasti dapat menyihir pendengarnya. Ada lagi gamelan kontemplatif, coba dengarkan gamelan sekaten, itu seperti orang berzikir yang setelah sampai langit lalu dibawa kembali ke bumi. Sama-sama logam ada logam mulia atau tosan aji atau wesi aji. Misalnya keris. Keris yang bukan semata-mata barang hiasan, khasiatnya macam-macam. Ada yang bisa untuk mendiagnosa penyakit, ada yang bisa menyembuhkan, dan ada yang bisa untuk nyumpah. $O$, ya. Saya pernah melihat sendiri keris yang bisa berdiri diujungnya, kabarnya karena ampuh atau perbuatan jin (Kuntowijoyo, 2013:35)".

Kutipan data tersebut menjelaskan bahwa gamelan dan keris merupakan benda yang terbuat dari logam dan perunggu. Keduanya dalam budaya Jawa juga memiliki posisi istimewa bagi sebagian besar masyarakat Jawa. Banyak masyarakat Jawa yang percaya bahwa gamelan dan keris merupakan benda yang memiliki daya magis dan daya mistik. Hal ini karena masyarakat percaya bahwa dalam kedua benda tersebut bersemayang sosok magis yang memberikan kekuatan supernatural. Hal ini sejalan dengan hasil penelitian yang menyebutkan bahwa, sebagian besar masyarakat Jawa beranggapan bahwa gamelan dan keris syarat akan muatan religius (Meitridwiastiti,
2018; Rohman, Laili, \& others, 2018). Gamelan bagi masyarakat Jawa dianggap sebagai salah satu alat yang dapat digunakan untuk berdakwah melalui musik. Sementara itu, keris bagi masyarakat Jawa juga dianggap sebagai salah satu benda yang memiliki daya magis tinggi.

Berdasarkan data di atas, benda yang memiliki proporsi lebih di tengah masyarakat Jawa adalah keris. Hal ini dikarenakan kekuatan magis yang dimiliki oleh keris lebih banyak dipercaya oleh masyarakat Jawa, sehingga mendorong sebagian besar masyarakat Jawa berlombalomba untuk memilikinya. Kepercayaan ini tidak hanya tumbuh pada kalangan masyarakat umum, tetapi juga pada masyarakat di lingkungan keratin (pejabat). Hal ini dikarenakan sebagian besar masyarakat Jawa masih menganggap bahwa keris merupakan benda keramat yang memiliki nilai mistik (Meitridwiastiti, 2018; Putri, Banda, \& Jumadiah, 2018; Rohman et al., 2018; Septiana, 2018). Keris sebagai benda keramat yang memiliki nilai mistik, menjadikan setiap pemiliknya untuk melakukan ritual untuk merawatnya, lebihlebih pada malam satu suro (Meitridwiastiti, 2018; Putri et al., 2018; Rohman et al., 2018; Septiana, 2018). Hal ini dilakukan dengan tujuan agar kesaktian dan daya magis keris tetap terjaga dan semakin meningkat.

Pada kutipan data tersebut, menunjukkan bahwa telah terjadi pergeseran makna dalam memahami fungsi keris di masyarakat Jawa. Keris hadir sebagai identitas, warisan budaya, dan alat tradisional masyarakat Jawa, sehingga bagi setiap individu yang memilikinya akan memberikan rasa bangga terhadap identitas budayanya. Akan tetapi, seiring perjalanan waktu, kepemilikan keris mengalami pergeseran makna. Dewasa ini, masyarakat Jawa yang memiliki keris telah menjadikannya sebagai benda keramat yang memiliki nilai mistik (Meitridwiastiti, 2018; Putri et al., 2018; Rohman et al., 2018; Septiana, 2018). Hal ini sejalan dengan pendapat Mulder (2013) yang menyatakan bahwa tingkatan yang paling dasar dari 
mistisisme Jawa adalah individu yang percaya dengan benda-benda mitologi seperti keris.

\subsection{Praktik Mistisisme Jawa pada Tingkatan Syareat dalam Bentuk Percaya pada Mitos-mitos}

Salah satu bentuk praktik mistisisme Jawa pada tingkatan syareat adalah bentuk kepercayaan terhadap mitos-mitos yang ada di tengah masyarakat. Mitos adalah kepercayaan masyarakat terhadap benda, tokoh, ataupun hal gaib. Dalam masyarakat Jawa, kepercayaan terhadap mitos tumbuh dengan subur. Hal ini terbukti dengan banyaknya mitos yang dimiliki oleh orang Jawa, mulai dari mitos pernikahan, mitos jodoh, mitos tanam padi, dan lain-lain. Mitos yang ada di masyarakat biasanya berkaitan dengan siklus kelahiran, kehidupan, dan kematian manusia di Bumi.

Mitos sebagai salah satu bentuk budaya yang telah turun-temurun yang dipercayai oleh masyarakat Jawa. Dalam praktiknya, mitos selalu berdampingan dengan perilaku yang ditunjukkan oleh masyarakat Jawa. Hal ini dapat ditunjukkan pada kutipan data berikut.

"Pada hari ke lima, diadakan sepasaran dengan mengundang macapatan dan gamelan sederhana, pembacaan macapat ditutup dengan kenduri dan doa yang dipimpin oleh modin desa. Dengan bangga kakek itu mengumumkan bahwa cucunya diberi nama Abu Kasan Sapari. Abu diambil dari nama sahabat Nabi Abu Bakar, Kasan adalah nama cucu Nabi, dan Sapar adalah bulan perkawinan kedua orang tuanya. Diharapkannya bahwa nama itu ada pengaruhnya pada jabang bayi yang baru lahir. Kemudian dengan suara serak seseorang tua melagukan Dandanggula, peninggalan Sunan Kalijaga yang berisi doa keselamatan (Kuntowijoyo, 2013:2-3)".

Kutipan data tersebut menunjukkan bahwa masyarakat Jawa masih memegang teguh mitos yang diturunkan secara turun- temurun oleh nenek moyang. Sebagian besar masyarakat Jawa selalu mengharapkan berkah dalam setiap proses kelahiran yang terjadi. Masyarakat Jawa mengharapkan berkah melalui kegiatan sepasaran dan pembacaan macapat dalam sebuah kenduri yang dipimpin oleh seorang modin desa. Sepasaran merupakan upacara adat Jawa yang dilakukan pada hari kelima setelah kelahiran bayi (Lantowa \& Bagtayan, 2017; Widyaningrum \& Tantoro, 2017). Adapun tujuan diadakannya sepasaran adalah sebagai salah satu bentuk syukur kepada Tuhan, serta memohon perlindungan agar bayi dapat hidup tentram dan dijauhkan dari segala macam penyakit (Lantowa \& Bagtayan, 2017).

Pelaksanaan sepasaran bagi masyarakat Jawa adalah rentetan kegiatan yang harus dilakukan setelah kelahiran bayi dalam satu keluarga. Kelahiran bayi dalam satu keluarga secara tidak langsung telah mengharuskan keluarga tersebut untuk melakukan serangkaian kegiatan, salah satunya adalah sepasaran. Masyarakat Jawa memiliki rangkaian tersendiri dalam melakukan bentuk syukur atas kelahiran bayi, dimulai dengan sewengenan (satu malam) dengan mengadakan brokohan (Safitri, Sinaga, \& Ekwandari, 2018), dilanjutkan dengan sepasaran (Widyaningrum \& Tantoro, 2017), aqiqah (Lantowa \& Bagtayan, 2017; Susanti, 2017), dan selapan (Sudardi \& others, 2015; Widyaningrum \& Tantoro, 2017).

Realitas pada era modern sekarang pelaksanaan sepasaran dan semua rentetan yang menyertainya perlahan telah sedikit mengalami pergeseran. Hal ini didasarkan pada semakin berkurangnya pelaksanaan sepasaran di kalangan masyarakat Jawa khususnya daerah perkotaan. Kondisi tersebut dikarenakan rentetan kegiatan setelah bayi dilahirkan terlalu banyak menyita waktu, tenaga, dan biaya (Safitri et al., 2018; Widyaningrum \& Tantoro, 2017), sehingga perlahan mulai ditinggalkan. Adapun rentetan kegiatan yang masih dipertahankan oleh masyarakat Jawa setelah kelahiran bayi adalah aqiqah. 
Praktik mistisisme Jawa lainnya yang masih kental dipertahankan oleh masyarakat Jawa, khususnya di pedesaan adalah percaya terhadap mitos pohon beringin tua yang memiliki kekuatan mistik. Hal ini dapat dibuktikan dalam kutipan data berikut.

\section{"Pohon beringin tua tumbuh lebat di terminal, tidak seorang pun tahu kapan ditanam dan siapa menanam. Begitu tua pohon itu, sehingga dulu ada orang yang menganggapnya bertuah. Orang yang akan mantu memakai rantingnya sebagai hiasan dengan harapan mempelai akan panjang umur subur makmur, mencari daun lumah-kurep (jatuh menghadap ke atas dan ke bawah) dengan harapan mempelai akan rukun, segera punya anak. Ringin artinya juga mari kepengin (tidak kepengin), sebab orang yang sudah kawin harus berhenti menginginkan pasangan. Tidak diketahui siapa yang memulai, tapi setiap bulan Mulud pasti ada pertunjukan wayang di situ. Kemudian perayaan itu tetap, namun orang sudah lupa dengan beringin bertuah dan menganggapnya perayaan itu sebagai bersih desa biasa. Pada waktu itulah warga desa Tegalpandan yang merantau datang untuk ziarah, bertemu keluarga, dan berkumpul dengan teman-teman lama (Kuntowijoyo, 2013:39)".}

Kutipan data tersebut menunjukkan bahwa masyarakat Jawa telah menganggap pohon beringin tua memiliki banyak kekuatan mistik tersendiri. Sebagian besar masyarakat Jawa banyak mempercayai bahwa ada berkah tersendiri yang dapat diberikan oleh pohon beringin. Bentuk mengharap berkah dari pohon beringin tersebut telah menjadi mitos secara turuntemurun di masyarakat Jawa. Dalam praktiknya banyak masyarakat yang mengharap berkah pada pohon beringin tua pada setiap acara pernikahan yang diselenggarakan. Hal ini dikarenakan banyaknya mitos yang masih dipegang erat oleh masyarakat bahwa seluruh anggota pohon beringin memiliki tuah bagi masyarakat Jawa yang akan melaksanakan pesta pernikahan (Mufiani, 2015).

Kutipan data di atas menunjukkan bahwa setiap ada pesta pernikahan, masyarakat Jawa selalu ngelurug/mencari ranting dan daun pohon beringin agar mendapatkan berkah untuk kedua mempelai (Lantowa \& Bagtayan, 2017). Sebagian besar masyarakat Jawa juga percaya bahwa pengantin yang akan menikah juga wajib berputar di pohon beringin tua agar mendapatkan keselamatan. Mitos lain yang dipegang teguh adalah pohon beringin merupakan tempat tinggal mahluk halus, sehingga setiap kali akan terjadi bencana, musibah, dan kematian pohon beringin selalu memberikan pertanda. Hal ini senada dengan hasil penelitian (Dewi \& Sumarjiana, 2014; Kariarta, 2019; Lantowa \& Bagtayan, 2017; Mufiani, 2015; Puspitasari, 2016; Wijanarti, 2019) yang mengupas habis mengenai mitos-mitos yang menyertai pohon beringin tua bagi masyarakat Jawa dan Bali.

Dalam sudut pandang ekologis, mitos tentang pohon beringin yang telah turuntemurun dipercaya oleh masyarakat Jawa merupakan salah satu upaya yang dilakukan untuk menjaga dan melestarikan alam. Hal ini sejalan dengan hasil penelitian (Savenny \& Dilliarosta, 2020) yang menjelaskan bahwa di balik mitos yang telah dipercaya oleh masyarakat, ada upaya yang dilakukan untuk konservasi alam. Mitos yang menyertai pohon beringin telah menekan tingkat penebangan liar yang dilakukan oleh manusia. Keuntungan lain dari mitos yang menyertai pohon beringin adalah terjaganya ekosistem alam karena fungsi dari pohon beringin yang sangat bervariatif. Dengan demikian, dapat dikatakan bahwa mitos yang melekat erat pada pohon beringin merupakan upaya yang baik dalam melestarikan keberlangsungan alam. Mitos lain yang juga masih dipegang teguh oleh masyarakat Jawa adalah adanya mantra yang harus diturunkan. Mitos mengenai mantra yang begitu dituakan dapat dilihat pada kutipan data berikut. 
"Begini. Kau terikat dengan perjanjian. Mantra pejinak ular itu harus langgeng, diturunkan dari generasi ke generasi. Mata rantai ilmu harus berlanjut, terusmenerus, dan abadi. Jadi, kau tidak bisa membuang begitu saja. Saya dulu juga mencari orang yang cocok dengan ilmu itu sampai tua. Kau tidak akan mati-mati sebelum menurunkan ilmu itu. Mengerti?" "Mengerti, Kek." "Sudah, saya pamit." Setelah Kakek pergi, Abu terbangun, tidak tertidur sampai azan Subuh tiba. Segera dia bangun, pergi ke surau. Ketika bertemu Haji Syamsuddin dikatakannya bahwa seusai shalat dia ingin bicara. Selesai shalat, kata Haji Syamsuddin: "Wah, ada apa?" Begini, Pak. Saya akan melaksanakan anjuran mengenai Ma'ul Hayat itu. Tapi ada halangan." "Halangan? Laki-laki harus berani, rawe-rawe rantas, malangmalang putung." "Bukan itu, Pak. Lastri minta saya menyingkirkan ular." "Apa susahnya? Bawa saja ular itu ke kebun binatang." "Ular mudah, Pak. Tapi saya terikat dengan mantranya." "Mantra?" "Ya, Pak. Saya harus mencari orang yang mau ditulari mantra. Mantra harus diturunkan, berkelanjutan sampai kiamat tiba. Kalau tidak saya kena bebendu [malapetaka], tidak akan mati-mati meski tua-renta "Jangan percaya! Itu gombal, itu sampah. Kau orang beriman. Karenaya malahan kau wajib memutuskan mata rantai sirik itu. Sekarang zaman modern, bukan zamannya mantra lagi (Kuntowijoyo, 2013:94).

Kutipan data di atas menunjukkan bahwa mantra merupakan salah satu kebudayaan masyarakat Jawa yang masih bertahan sampai saat ini. Banyak masyarakat Jawa yang masih mendasarkan setiap kegiatan yang mereka lakukan pada mantra. Tujuan utamanya adalah mendapatkan kelancaran atau kekuatan yang melindungi diri dengan merapalkan mantra yang diberikan oleh guru spiritual atau guru supranatural (Saddhono, 2016). Rapalan mantra yang diucapkan tidak hanya sekedar deratan kata melainkan gagasan sebagai penegasan suatu tujuan tertentu yang mengandung kekuatan gaib (Lantowa \& Bagtayan, 2017; Saddhono, 2016).

Pada praktiknya, masyarakat Jawa masih sangat memegang teguh bahwa rapalan mantra yang sudah dimilikinya harus diturunkan dan diwariskan. Hal ini sebagai salah satu syarat yang harus dilakukan agar individu yang memiliki mantra tidak mengalami musibah atau terkena kutukan. Oleh karena itu, setiap individu yang telah memiliki rapalan mantra selalu mencari suksesinya untuk melanjutkan rapalan mantra tersebut di kemudian hari. Bentuk kepercayaan terhadap mantra ini telah mejadi salah satu sistem kepercayaan yang dipegang teguh oleh masyarakat Jawa sampai hari ini (Lantowa \& Bagtayan, 2017).

Rapalan mantra bagi masyarakat Jawa bukan hanya deretan kata, melainkan salah satu gagasan sebagai penegas tujuan yang bersifat positif. Sayangnya pada praktiknya, masih banyak mantra yang digunakan untuk hal tidak sewajarnya. Hal ini sejalan dengan contoh sederhana berkaitan dengan rapalan mantra yang digunakan oleh anak muda untuk memikat lawan jenis, rapalan mantra yang digunakan oleh pejabat untuk melanggengkan kekuasaannya, serta para perempuan penjaja seks komersial juga merapalkan mantra guna memikat lelaki hidung belang (Saddhono, 2016). Rapalan mantra yang digunakan oleh setiap individu dapat berupa benda, ucapan, atau doa khusus yang diberikan oleh guru spiritual. Praktik mistisisme Jawa lainnya yang masih dipegang teguh oleh masyarakat Jawa adalah mengani arah angin. Arah angin menjadi salah mitos yang masih bertahan di tengah masyarakat, lebih-lebih ketika akan membangun dan memasuki rumah. Hal ini dapat dibuktikan dengan kutipan data berikut.

"Rumah orang Jawa menghadap ke utara
atau selatan, tidak timur atau barat,
ternyata ada hubungannya dengan angin.
Hanya masjid dan surau menghadap ke
timur. Dulu alasannya menghadap utara
atau selatan karena meniru atau
menghadap keraton. Itu sah-sah saja, 
tapi yang penting soal angin itu. Angin membawa embun dari laut, lalu jadi awan, lalu jadi hujan. Lalu dari hujan tumbuh pohon. Lalu pohon-pohon berkumpul, jadi hutan. Untuk mengundang angin, anak-anak akan menyanyi, "Mbok-mbok pe, mbok pe, barata sing gedhe, tak opahi duduh tape" (Kuntowijoyo, 2013: 29).

Kutipan data tersebut menunjukkan bahwa masyarakat Jawa masih percaya terhadap arah angin dalam membangun rumah. Pembangunan rumah yang akan dilakukan selalu didasarkan pada empat arah angin yaitu utara, selatan, timur, barat (Subiyantoro, 2011). Selain keempat arah tersebut, masyarakat Jawa mengenal empat arah angin lainnya yaitu lor wetan (timur laut), lor kulon (barat laut), kidul wetan (tenggara), dan kidul kulon (barat daya) (Aji, 2010). Berdasarkan pembagian arah angin tersebut dapat ditarik benang merah bahwa oposisi utara-selatan sebagai arah, posisinya terletak di awal mendahului arah timur-barat (Aji, 2010). Oposisi utara-selatan inilah yang dijadikan sebagai dasar dalam membangun rumah bagi masyarakat Jawa, sehingga didapati sebagian besar rumah masyarakat Jawa menghadap ke utara atau selatan.

Arah angin yang dijadikan sebagai dasar dalam penentuan arah rumah masyarakat Jawa tidak terlepas dari unsur mitos yang melatarbelakanginya. Di kalangan masyarakat Jawa arah angin memiliki fungsi sebagai salah satu alat untuk menyelaraskan dengan alam (Subiyantoro, 2011). Arah rumah yang menghadap ke selatan dan utara merupakan mitos yang dihadirkan guna menghormati Nyi Rara Kidul sebagai penguasa pantai selatan (Subiyantoro, 2011). Dalam mitos yang dipercayai masyarakat Jawa, arah selatan merupakan representasi Nyi Rara Kidul penguasa air, serta merupakan bentuk penghormatan terhadap air yang mengandung makna kemakmuran (Subiyantoro, 2011). Arah angin utara menurut masyarakat Jawa merupakan representasi sumber kehidupan.
Perpaduan kedua arah angin tersebut bagi masyarakat Jawa memiliki makna sumber kehidupan dan kemakmuran bagi penghuninya (Subiyantoro, 2011). Selain dua arah angin tersebut, masyarakat Jawa juga mempercayai mitos bahwa arah angin barat-timur juga sangat baik. Kepercayaan tersebut didasarkan pada realitas muncul dan tenggelamnya matahari dari arah timurbarat. Matahari sendiri dimaknai oleh masyarakat Jawa sebagai sumber energi yang sangat bermanfaat dalam kehidupan sehari-hari (Subiyantoro, 2011). Selain itu, matahari juga dimaknai sebagai penanda waktu dalam perputaran kehidupan oleh masyarakat Jawa. Berdasarkan penyataan tersebut, dapat ditarik kesimpulan bahwa pembangunan rumah mengikuti arah angin yang paling dominan yaitu utara-selatan yang bermakna sumber kehidupan dan kemakmuran bagi penghuninya (Subiyantoro, 2011).

\subsection{Praktik Mistisisme Jawa pada Tingkatan Hakekat dalam Bentuk Ibadah sebagai Upaya Untuk Menemui Tuhan}

Praktik mistisisme Jawa pada tingkatan hakekat merupakan tingkatan yang lebih kompleks daripada syariat. Tingkatan hakekat dibuktikan dengan upaya yang sungguh-sungguh dilakukan dalam beribadah sebagai upaya untuk menemui Tuhan (Mulder, 2013). Dalam praktiknya, tingkatan hakekat tidak banyak dapat dilakukan oleh semua orang karena membutuhkan upaya yang lebih di atas kepercayaan yang dimiliki. Pada masyarakat Jawa, praktik ini biasanya dilakukan oleh orang-orang yang benar-benar telah menyerahkan dirinya kepada Yang Maha Kuasa. Bagi pelaku praktik ini, segala hal yang ada di dunia bukanlah tujuan, tetapi sarana untuk mencapai tujuan bertemu Tuhan yang Maha Esa. Hal ini dapat ditunjukkan pada kutipan data berikut.

\footnotetext{
"Begini, Dimas. Adapun maksud kedatangan saya pertama ialah untuk silaturahmi, menyambung persaudaraan. Kedua, tidak kalah penting dari yang
} 
pertama. Saya merasa sudah diselamatkan oleh almarhum Bapak di sini, waktu malaise dua tahun saya tinggal di sini. Kalau Dimas mengizinkan biarlah saya membalas budi almarhum dengan mengangkat nak Abu Kasan Sapari sebagai anak. Jangan khawatir, setiap minggu dia bisa pulang ke sini. Mungkin Palur lebih dekat ke Solo dari pada sini. Itu kalau dia berminat melanjutkan sekolah, dari pada mondok. Wong rumah saya kosong, anak-anak sudah pergi." "Wah, itu persoalan besar, Kangmas. Saya berunding dulu dengan orang tuanya."

"Kami berharap sekali. Wah, itu persoalan besar, Kangmas. Saya berunding dulu dengan orang tuanya." "Kami berharap sekali." Musyawarah antara kakek-nenek dan orang tuanya hanya menghasilkan bahwa segalanya terserah Abu sendiri. Dan ia mengatakan akan sembahyang istikharah, maneges kersaning Allah, menanyakan kehendak Tuhan. Pagi harinya ia menyatakan 'ya', setelah bermimpi naik traptrapan memasuki suatu gedung. Tidak ada kesulitan dia masuk Sekolah Tinggi Seni Indonesia (STSI) di Surakarta jurusan pedalangan. Tinggallah dia di Palur di rumah Ki Lebdo" (Kuntowijoyo, 2013: 29)".

Kutipan data tersebut menunjukkan bahwa dalam setiap pengambilan keputusan harus selalu melibatkan Allah. Pelibatan Allah dalam mengambil keputusan akan memberikan dampak yang bersifat jangka panjang bagi pengambil keputusan. Mistisisme Jawa pada tingkatan hakekat dapat diwujudkan dalam rangkaian ibadah yang lebih dari sekedar percaya terhadap Allah, melainkan dengan tindakan atau upaya untuk mewujudkan kepercayaan itu dengan ibadah. Dalam praktiknya, mistisisme Jawa pada tingkatan hakekat dapat diwujudkan dengan salat tahajud, salat istikharah, salat hajat, dan rentetan salat malam lainnya (Alviah \& Tresnawati, 2015).
Salat istikharah merupakan salah satu salat yang dilakukan untuk mengambil keputusan terhadap satu hal.

Dalam perspektif masyarakat Jawa, salat istikharah merupakan ibadah yang harus dilakukan sebagai salah satu bukti dari percaya kepada Allah. Salat Istikharah merupakan salah salat sunah yang dapat dilakukan kapan pun, kecuali di waktu larangan untuk melaksanakan salat sunah (Sari, Rosyid, \& Romli, 2017). Waktu terbaik untuk menjalankan salat istikharah adalah di sepertiga malam setelah melaksanakan salat wajib isya (Munir, 2017; Sari et al., 2017). Tujuan utama salat istikharah adalah mencari jawaban atau keputusan yang akan diambil dalam menyikapi satu hal, sehingga keputusan yang diambil tidak didasarkan hanya pada hawa nafsu semata (Munir, 2017; Sari et al., 2017). Dengan waktu pelaksanaan dan tujuan dari salat istikharah, tentu ini merupakan salah satu praktik mistisisme pada tingkatan yang lebih kompleks daripada syariat. Hal ini didasarkan bahwa salat istikharah merupakan sebuah upaya yang lebih di atas kepercayaan yang dimiliki oleh individu. Selain itu, waktu pelaksanaannya yang lebih baik dilaksanakan pada sepertiga malam juga merupakan tantangan tersendiri bagi siapa pun yang akan melaksanakannya.

\section{Kesimpulan}

Penelitian ini bertujuan mendeskripsikan praktik mistisisme Jawa yang tergambarkan dalam novel Mantra Pejinak Ular karya Kuntowijoyo. Berdasarkan hasil analisis yang telah dilakukan dalam penelitian ini, dapat disimpulkan bahwa dalam novel Mantra Pejinak Ular karya Kuntowijoyo merepresentasikan praktik mistisisme Jawa pada tingkatan sarengat/syariat dan hakekat. Pada tingkatan sarengat/syariat, praktik mistisisme Jawa diwujudkan dalam bentuk percaya pada benda mitologi dan percaya pada mitos-mitos di tengah masyarakat. (1) Praktik mistisisme Jawa dalam bentuk percaya pada benda mitologi ditemukan 
dalam bentuk sebagian masyarakat Jawa masih percaya dan mengeramatkan keris sebagai benda yang memiliki kekuatan mistik. (2) Praktik mistisisme Jawa dalam bentuk percaya pada mitos-mitos ditemukan dalam bentuk (a) sepasaran, (b) mengharap berkah dari pohon beringin, (c) mencari penerus rapalan mantra, dan (d) mengharap berkah dari pembangunan rumah berdasarkan arah angin. Tingkatan praktik mistisisme Jawa yang kedua adalah hakekat, pada tingkatan ini diwujudkan dalam bentuk ibadah sebagai upaya untuk bertemu dengan Tuhan. Ibadah yang dilakukan sebagai upaya untuk bertemu dengan Tuhan diwujudkan dalam bentuk salat istikharah. Salat istikharah merupakan salat sunah yang dapat dilaksanakan kapan pun, kecuali di waktu larangan untuk melaksanakan salat sunah. Namun lebih baik apabila dilaksanakan pada sepertiga malam dengan didasari kekhusyukkan sebagai salah satu bentuk komunikasi dengan Tuhan. Dengan demikian, penelitian tentang praktik mistisisme Jawa dalam novel Mantra Pejinak Ular karya Kuntowijoyo ini dapat menjadi bahan perenungan bagi para pembaca, sehingga karya sastra berperan lebih besar dalam memberikan pemahaman tentang nilai budaya Jawa yang telah tumbuh di tengah masyarakat.

\section{Ucapan Terima Kasih}

Penulis mengucapkan terima kasih kepada pihak-pihak yang telah membantu terselesaikannya naskah ini dengan baik. Terkhusus penulis sampaikan pada Direktorat Penelitian dan Pengabdian pada Masyarakat (DPPM) Universitas Muhammadiyah Malang yang telah memberikan dukungan dan pendanaan dalam penelitian ini.

\section{Daftar Pustaka}

Aji, D. C. (2010). Konsepsi Arah Bagi Orang Jawa (Tinjauan Antropologi Linguistik). Adabiyyat: Jurnal Bahasa Dan Sastra, 9(1), 47-60. https://doi.org/https://doi.org/10.14 421/ajbs.2010.09103
Aksan, S. M. (2018). Corak Epistemologi Mistis Neoplatonisme dalam Mistisisme Islam. Intizar, 24(2), 235-252.

https://doi.org/10.19109/intizar.v2 $4 \mathrm{i} 2.3101$

Alviah, S. A., \& Tresnawati, D. (2015). Pengembangan Aplikasi Tuntunan Shalat Malam Menggunakan Sistem Multimedia. Jurnal Algoritma, 12(1), 132-138. Retrieved from https://www.jurnal.sttgarut.ac.id/in dex.php/algoritma/article/view/170

Budiman, R. (2016). Representasi mistisisme dan seksualitas: Penerjemahan budaya dalam tiga film eksploitasi dari Indonesia. Makna (Jurnal Kajian Komunikasi, Bahasa, Dan Budaya), 1(2), 49-61. https://doi.org/https://doi.org/10.33 558/makna.v1i2.808

Bukhori, Z. (2012). Mistisisme Islam Jawa: studi Serat Sastra Gendhing Sultan Agung. IAIN Walisongo.

Chalik, A. (2015). Sintesis mistik dalam kepemimpinan politik Jawa. Jurnal Review Politik, 5(2), 254-278. Retrieved from http://jurnalfuf.uinsby.ac.id/index. php/JRP/article/view/1104

Creswell, J. W. (2014). Research design: Qualitative, quantitative and mixed methods approaches. Thousand Oaks, CA: Sage Publications Inc.

Dewi, A. A. P. C. P., \& Sumarjiana, I. K. L. (2014). Persepsi Masyarakat di Balik Mitos Pohon Beringin di Pura Kehen Desa Adat Cempaga, Kecamatan Bangli, Kabupaten Bangli. Jurnal Santiaji Pendidikan, 4(1), 1-7.

Djono, D., Utomo, T. P., \& Subiyantoro, S. (2012). Nilai Kearifan Lokal Rumah Tradisional Jawa. Humaniora, 24(3), 269-278. 
Furqon, S., \& Busro, B. (2017). Doktrin mistisisme Al-Ghazali (Sufisme sebagai etape perjalanan spiritual). Syifa Al-Qulub, 2(1), 35-46. https://doi.org/10.15575/saq.v2i1.2 392

Ichsan, Y., \& Hanafiah, Y. (2020). Mistisisme Dan Transendensi Sosio-Kultural Islam Di Masyarakat Pesisir Pantai Parangkusumo Yogyakarta. Fikri: Jurnal Kajian Agama, Sosial Dan Budaya, 5(1), 21-36.

Kariarta, I. W. (2019). Kontemplasi diantara Mitos dan Realitas (Contemplation Between Myths and Realities).

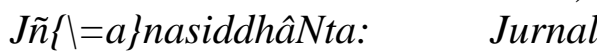
Teologi Hindu, 1(1), 37-47. Retrieved from http://jurnal.stahnmpukuturan.ac.id /index.php/jnanasidanta/article/vie w/344

Kasanova, R., \& Widjajanti, S. (2018). Mitos dan kontramitos dalam novel mantra penjinak ular karya kuntowijoyo. Deiksis: Jurnal Pendidikan Bahasa Dan Sastra Indonesia, 5(2), 102-111. https://doi.org/http://dx.doi.org/10. 33603/deiksis.v5i2.1141

Kuntowijoyo. (2013). Mantra Pejinak Ular. Jakarta: Penerbit Buku Kompas.

Lantowa, J., \& Bagtayan, Z. A. (2017). Sistem Religi Masyarakat Jawa dalam Novel Mantra Pejinak Ular Karya Kuntowijoyo (Kajian Antropologi Sastra). Jurnal IKADBUDI, 6(1), 79-93. https://doi.org/https://doi.org/10.21 831/ikadbudi.v6i1.18198

Mardiani, N. (2017). The Reflection of Rural Society's Life in the Novel Mantra Penjinak Ular by Kuntowijoyo A Study of Literature Sociology. ALAYASASTRA, 13(1),
92-101.

Mashadi, M. (2013). Konteks dan corak mistisisme Islam dalam tradisi keagamaan masyarakat Gorontalo. Ulumuna, 17(2), 259-274. https://doi.org/https://doi.org/10.20 414/ujis.v17i2.162

Meitridwiastiti, A. A. A. (2018). Teks Naratif dari Mitos Keris Ki Baru Gajah dalam Tradisi Ngrebeg. Linguistika, 25(1), 1-6. https://doi.org/https://doi.org/10.24 843/ling.2018.v25.i01.p01

Miles, M. B., \& Huberman, A. M. (1994). Qualitative data analysis: An expanded sourcebook. London: SAGE Publications Inc.

Miswari, M. (2017). Filosofi komunikasi spiritualitas: Huruf sebagai simbol ontologi dalam mistisme Ibn 'Arab. AL-HIKMAH: Media Dakwah, Komunikasi, Sosial Dan Budaya, 8(1), 12-30. https://doi.org/https://doi.org/10.32 505/hikmah.v8i1.397

Mufiani, I. (2015). Mitos Mbah Bregas Di Dusun Ngino Desa Margoagung Seyegan Sleman Yogyakarta (Studi Terhadap Klasifikasi, Pandangan Dan Fungsi Mitos). Religi: Jurnal Studi Agama-Agama, 11(2), 17-37. https://doi.org/https://doi.org/10.14 421/rejusta.2015.1102-02

Mulder, N. (2013). Mistisisme Jawa ideologi di Indonesia. Yogyakarta: LKiS.

Munir, A. K. M. (2017). Nilai-nilai pendidikan akhlak yang terkandung pada novel dalam mihrab cinta karya habiburrahman el-shirazy. Jurnal Al-Murabbi, 3(1), 101-120. Retrieved from https://jurnal.yudharta.ac.id/v2/ind ex.php/pai/article/view/896 
Nawafi, A. Y. F. (2020). Titik temu mistisisme Islam dan mistisisme Jawa; Studi analitis terhadap persinggungan ajaran tasawuf dan kejawen. Jurnal Intelektual: Jurnal Pendidikan Dan Studi Keislaman, 10(2), 242-254. https://doi.org/https://doi.org/10.33 367/ji.v10i2.1297

Parini, S. (2014). Aspek Religiusitas Novel Mantra Pejinak Ular Karya Kuntowijoyo: Kajian Semiotik dan Implementasinya Sebagai Bahan Ajar Sastra Di SMP. Jurnal Penelitian Humaniora, 15(1), 5565.

Puspitasari, R. (2016). Mitos dalam Novel Tembang Tolak Bala Karya Han Gagas. Jurnal Bahasa Dan Sastra, 3(1), 57-63. Retrieved from https://jurnal.lppmstkipponorogo.a c.id/index.php/JBS/article/view/63

Putri, S. S. D. J., Banda, M. M., \& Jumadiah, S. (2018). Mitos Keris dalam Novel Hunus Karya Sunaryono Basuki Ks. Humanis, 22(3), 572-578. https://doi.org/https://doi.org/10.24 843/JH.2018.v22.i03.p01

Rohman, F., Laili, R., \& others. (2018). Keris dalam Tradisi Santri dan Abangan. Kontemplasi: Jurnal Ilmu-Ilmu Ushuluddin, 6(1), 7998.

https://doi.org/https://doi.org/10.21 274/kontem.2018.6.1.79-98

Rudin, T. (2017). Ajaran taoisme dan mistisisme Islam (studi komparatif). Jurnal Intelektualita: Keislaman, Sosial Dan Sains, 6(2), 271-294.

https://doi.org/10.19109/intelektua lita.v6i2.1611

Saddhono, K. (2016). Dialektika Islam dalam mantra sebagai bentuk kearifan lokal Budaya Jawa. AKADEMIKA: Jurnal Pemikiran
Islam, 21(1), 83-98. Retrieved from https://ejournal.metrouniv.ac.id/index.php/ akademika/article/view/457

Safitri, R. Y., Sinaga, R. M., \& Ekwandari, Y. S. (2018). Persepsi Masyarakat Jawa terhadap Tradisi Brokohan di Desa Jepara Kabupaten Lampung Timur. PESAGI (Jurnal Pendidikan Dan Penelitian Sejarah), 6(1), 1-12.

Sari, T. M., Rosyid, A., \& Romli, R. (2017). Perkawinan Adat Jawa Perspektif Hukum Islam di Desa Terlangu Kecamatan Brebes. AlMashlahah Jurnal Hukum Islam Dan Pranata Sosial, 5(10), 805824.

https://doi.org/http://dx.doi.org/10. 30868/am.v5i10.473

Savenny, D. U., \& Dilliarosta, S. (2020). Konservasi Alam Mengenai Pohon di Daerah Padang. SEMESTA: Journal of Science Education and Teaching, 3(1), 19-29. https://doi.org/https://doi.org/10.24 036/semesta/vol3-iss 1/71

Septiana, A. (2018). Makna Nama-nama Keris di Keraton Kasunanan Surakarta. Sutasoma: Jurnal Sastra Jawa, 6(1), 1-20. https://doi.org/https://doi.org/10.15 294/sutasoma.v6i1.29054

Setiawan, A., \& Musaffak, M. (2019). Eksistensi mistisisme dalam novel Amba karya Laksmi Pamuntjak. KEMBARA: Jurnal Keilmuan Bahasa, Sastra, Dan Pengajarannya (e-Journal), 5(2), 146-156.

https://doi.org/10.22219/kembara. v5i2.9672

Setiawan, A., \& Musaffak, M. (2020). Praktik mistisisme Jawa dalam novel Partikel karya Dewi Lestari. KEMBARA: Jurnal Keilmuan Bahasa, Sastra, Dan 
Pengajarannya (e-Journal), 6(2), 267-278.

https://doi.org/https://doi.org/10.22 219/kembara.v6i2.15249

Subiyantoro, S. (2011). Rumah tradisional joglo dalam estetika tradisi jawa. Bahasa Dan Seni: Jurnal Bahasa, Sastra, Seni, Dan Pengajarannya, 39(1), 68-78.

Sudardi, B., \& others. (2015). Ritual dan nilai islami dalam folklor Jawa. IBDA: Jurnal Kajian Islam Dan Budaya, 13(2), 112-122. https://doi.org/https://doi.org/10.24 090/ibda.v13i2.665

Sumiyardana, K. (2018). Kesesuaian Masyarakat Jawa dalam Novel Mantra Pejinak Ular dengan Realita: Analisis Sosiologi Sastra. Madah, 8(2), 211-222.

Susanti, R. D. (2017). Tradisi Kenduri Dalam Masyarakat Jawa Pada Perayaan Hari Raya Galungan di Desa Purwosari Kecamatan Tegal Dlimo Kabupaten Banyuwangi. Jurnal Penelitian Agama Hindu, 1(2), 489-495.

Thalib, A. (2014). Perkembangan Mistisisme dalam Islam dan Maqomatnya. Sulesana: Jurnal Wawasan Keislaman, 9(1), 49-70. https://doi.org/https://doi.org/10.24 252/.v9i1.2874

Thohir, U. F. (2012). Pemikiran Mistisisme Annemarie Schimmel. ULUL ALBAB Jurnal Studi Islam, 13(2), 203-218.

https://doi.org/https://doi.org/10.18 860/ua.v0i0.2376

Wahidi, A. (2013). Mistisisme sebagai jembatan menuju kerukunan umat beragama. ULUL ALBAB Jurnal Studi Islam, 14(2), 135-146. https://doi.org/https://doi.org/10.18 860/ua.v14i2.2653
Wardhani, N. W., Arditama, E., Noe, W., \& Narimo, S. (2021). Merawat Mistisisme Dalam Tradisi Ngalap Berkah Sebagai Upaya Menjaga Tatanan Sosial Masyarakat di Surakarta. Jurnal Antropologi: IsuIsu Sosial Budaya, 23(1), 93-100. https://doi.org/https://doi.org/10.25 077/jantro.v23.n1.p93-100.2021

Widijanto, T. (2018). Dunia halus mistis Jawa dan fantasi magis Ternate dalam Godlob dan Cala Ibi. Jentera: Jurnal Kajian Sastra, 7(1), 102-129.

Widyaningrum, L., \& Tantoro, S. (2017). Tradisi Adat Jawa dalam Menyambut Kelahiran Bayi (Studi Tentang Pelaksanaan Tradisi Jagongan Pada Sepasaran Bayi) di Desa Harapan Harapan Jaya Kecamatan Pangkalan Kuras Kabupaten Pelalawan. JOM FISIP, 4(2), 1-15.

Wijanarti, T. (2019). Masyarakat Dayak Dan Alam: Sebuah Pembacaan Ekokritik Sastra Terhadap Cerita Pendek "Menari Di Puncak Beringin" Karya Budi Dayak Kurniawan. Jurnal Undas, 12(2), 135-144. Retrieved from https://core.ac.uk/download/pdf/27 0214601.pdf

Windayanto, R. N. A. (2020). Mistisisme Jawa dalam cerpen Anjing-anjing Menyerbu Kuburan karya Kuntowijoyo: Tinjauan Realisme Magis Wendy B. Fariz. Neologia: Jurnal Bahasa Dan Sastra Indonesia, 1(3), 160-174. Retrieved from http://103.76.50.195/Neologia/arti cle/view/18902/10046

Yudari, A. A. K. S. (2019). Apresiasi Mistisisme Jawa Pada Masyarakat Di Bali. Dharmasmrti: Jurnal Ilmu Agama Dan Kebudayaan, 19(2), 110. 
Jurnal Satwika : Kajian Ilmu Budaya dan Perubahan Sosial

Vol. 5, No. 2, Oktober 2021, pp. 337-352

https://doi.org/https://doi.org/10.32

795/ds.v19i2.433 